\title{
Mild Acidosis Delays Hypoxic Spreading Depression and Improves Neuronal Recovery in Hippocampal Slices
}

\author{
Geoffrey C. Tombaugh \\ Department of Cell Biology, Duke University Medical Center, Durham, North Carolina 27710
}

\begin{abstract}
Severe tissue acidosis has been viewed traditionally as a damaging component of cerebral hypoxia. However, a neuroprotective action of low $\mathrm{pH}$ during hypoxia has been described in primary neuronal cultures. To identify and characterize this effect in mature brain tissue, adult rat hippocampal slices were made hypoxic after adjusting $\mathrm{pH}_{0}$ with $\mathrm{HCl}$ or $\mathrm{NaOH}$. Ion-selective microelectrodes were positioned in CA1 to record evoked field potentials, extracellular DC voltage $\left(V_{o}\right), \mathrm{pH}_{o}$, and $\left[\mathrm{Ca}^{2+}\right]_{o}$. Orthodromic population spike amplitude was used as a measure of slice recovery $2 \mathrm{hr}$ after reoxygenation. All slices became markedly acidotic during hypoxia ( $\triangle \mathrm{pH}_{\mathrm{o}} \sim 0.4 \mathrm{pH}$ unit). Following restoration of $\mathrm{O}_{2}$ and bath $\mathrm{pH}$ to 7.4, slice $\mathrm{pH}_{0}$ returned to its pretreatment level regardless of experimental treatment, hypoxic duration, or the degree of electrophysiological recovery. When either the period of hypoxia or the duration of HSD was held constant, acid-treated slices exhibited a significant improvement in recovery. However, in neither paradigm did the recovery of alkaline-treated slices differ from controls. Mild acidosis (bath $\mathrm{pH}=6.9-7.3$ ) caused a reversible depression of the orthodromic population spike, an increase in the latency of hypoxic spreading depression-like depolarization (HSD), and a decrease in the magnitude of the associated negative $V_{0}$ shift. For each of these parameters, mild alkalinity (bath $\mathrm{pH}=7.7$ ) had the opposite effect. Acid treatment did not affect the decrease in $\left[\mathrm{Ca}^{2+}\right]_{0}$ during HSD but accelerated its recovery after reoxygenation. These results suggest that mild acidosis may limit hypoxic neuronal injury in vitro by delaying HSD onset and by additional mechanisms unrelated to the degree of calcium influx during neuronal depolarization.
\end{abstract}

[Key words: acidosis, hypoxia, anoxic depolarization, hippocampus, calcium, microelectrodes]

A characteristic feature of hypoxic brain tissue is the sudden and gross redistribution of ions across cell membranes. This event has been labeled hypoxic spreading depression-like depolarization (HSD) (Aitken et al., 1991) due to its similarity with the spreading depression of Leao (1944), which can be

\footnotetext{
Received Aug. 24, 1993; revised Mar. 1, 1994; accepted Mar. 15, 1994.

I am indebted to Dr. George Somjen and Dr. Peter Aitken (Department of Cell Biology, Duke University) for their expert advice and encouragement. I am also grateful to Dr. Mitchell Chesler and Dr. Robert Sapolsky for their critical readings of this manuscript. Support for this work was provided to G.C.T. by an NIH training grant and the National Stroke Association, and to G. G. Somjen by NIH Grants 5P01 NS17771 and 5R01 NS18670.

Correspondence should be addressed to Dr. Geoffrey C. Tombaugh, Department of Cell Biology, Box 3709, Duke University Medical Center, Durham, NC 27710. Copyright (C) 1994 Society for Neuroscience $0270-6474 / 94 / 145635-09 \$ 05.00 / 0$
}

evoked in normoxic brain tissue by various stimuli. The term "HSD" is used to emphasize this similarity without necessarily implying that the two are identical. HSD is a well-described pathophysiological state, but its relationship to neuronal injury is unclear. HSD waves (or anoxic depolarizations) are commonly scen during both global and focal ischemia and have been implicated in the neurotoxic process (Hansen and Nedergaard, 1988; Iijima et al., 1992; Chen et al., 1993). During HSD, neurons undergo a large and sustained rise in intracellular calcium (Mitani et al., 1993) and lowering $\left[\mathrm{Ca}^{2+}\right]_{o}$ has been shown to reduce hypoxic neuronal injury in vitro without preventing HSD (Balestrino and Somjen, 1986; Roberts and Sick, 1988; Amagasa et al., 1990; Young et al., 1992), suggesting that $\mathrm{Ca}^{2+}$ entry during HSD is critical. Such studies have depicted calcium as the underlying trigger for ischemic neuropathology, but it is clear that many factors during ischemia govern neuronal fate, not all of which necessarily play a damaging role.

Surprisingly, one important protective event may be a fall in tissue $\mathrm{pH}$. Acidosis is a hallmark of cerebral hypoxia and has received considerable attention since its description nearly 40 years ago (Thorn and Hietmann, 1954; Crowell and Kaufmann, 1961; Ljunggren et al., 1974). Ischemic acidosis has becn correlated with the extent of brain injury, and treatments that enhance this acidity often exacerbate tissue damage (Myers, 1979; Siesjo, 1988). Severe acidosis by itself is clearly capable of damaging brain cells: the toxicity of low-pH solutions has been well documented both in vitro and in vivo (Kraig et al., 1987; Goldman et al., 1989; Giffard et al., 1990a; Tombaugh and Sapolsky, 1990b). A causal link between severe acidosis and pannecrotic brain infarction appears well established (Plum, 1983; Kraig, 1985; Nedergaard, 1987), but such a connection between acidosis and selective neuronal injury is more tenuous (Tombaugh and Sapolsky, 1993). In vivo, hyperglycemia exacerbates ischemic acidosis and delays the onset of anoxic depolarization (Hansen, 1978; Ekholm et al., 1993) while it reduces both HSD frequency and neuronal injury in the penumbra of developing infarcts (Nedergaard and Diemer, 1987; Nedergaard, 1988). In vitro, extracellular acidity can inhibit NMDA-mediated cell currents, reduce neuronal $\left[\mathrm{Ca}^{2+}\right]_{i}$ accumulation, and prevent hypoxic neuronal injury (Schurr et al., 1988; Giffard et al., 1990a; Sher, 1990; Tang et al., 1990; Tombaugh and Sapolsky, 1990a, b; Traynelis and Cull-Candy, 1990; Takadera et al., 1992), all at $\mathrm{pH}$ values commonly seen in the ischemic brain (Siemkowicz and Hansen, 1981).

This study examines the relationship between $\left[\mathrm{H}^{+}\right]_{o}$, HSD, and the degree of neuronal injury induced by hypoxia in adult rat hippocampal slices. Tissue slices were exposed to brief periods of hypoxia after adjusting the ambient $\mathrm{pH}$ by small steps 


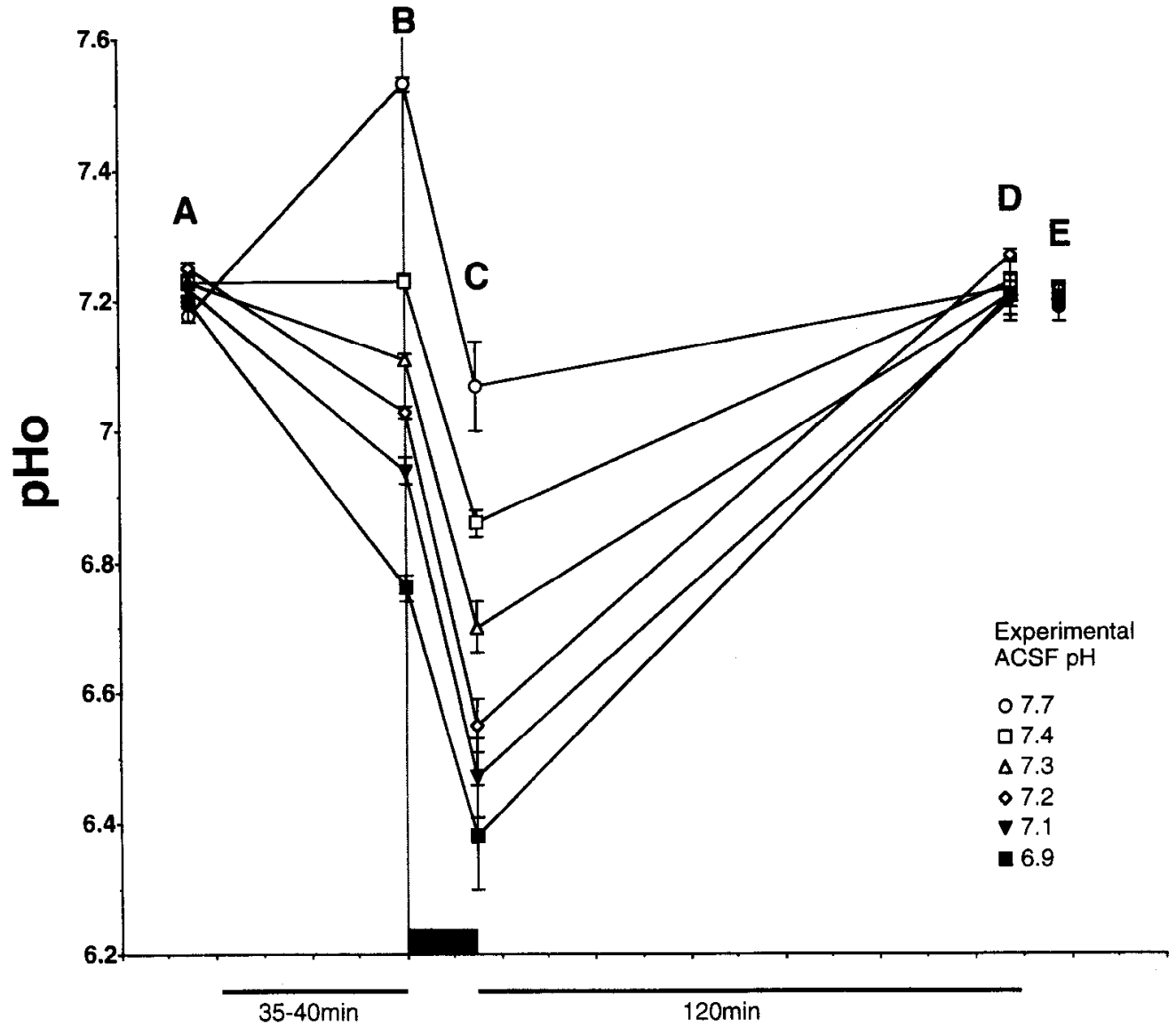

Figure 1. Summary of $\mathrm{pH}_{o}$ changes in slices treated with slightly acidic or alkaline ACSF before and during hypoxia (heavy bar). Because the peak acid shift and its recovery after $8 \mathrm{~min}$ of hypoxia did not differ from experiments in which hypoxia was prolonged, data from all experiments were combined ( $n \geq 5$ per group). Following hypoxia, normal ACSF (pH 7.4) was restored and $\mathrm{pH}_{o}$ monitored for $2 \mathrm{hr}$. $\mathrm{pH}_{\text {o }}$ was determined at a depth where the evoked orthodromic population spike was maximal and was calculated relative to bath $\mathrm{pH}$ prior to any treatment $(A)$, after exposure to experimental ACSF but before hypoxia $(B)$, after hypoxia $(C)$, and following a $2 \mathrm{hr}$ recovery period $(D)$. For comparison, posthypoxic $\mathrm{pH}_{o}$ was also calculated relative to bath $\mathrm{pH}(E)$ at the end of each experiment.

$120 \mathrm{~min}$

with either strong acid or base. Shifts in extracellular $\mathrm{pH}\left(\mathrm{pH}_{o}\right)$, $V_{o}$, and $\left[\mathrm{Ca}^{2+}\right]_{o}$ were monitored with ion-selective electrodes to determine whether such changes were associated with changes in neuronal recovery.

\section{Materials and Methods}

Hippocampal slice preparation. Transverse slices $(400 \mu \mathrm{m})$ were prepared from the middle third of hippocampi removed from male SpragueDawley rats $(125-150 \mathrm{gm})$ immediately following decapitation under ether anesthesia (Aitken, 1985). Dissections were performed in chilled $\left(4^{\circ} \mathrm{C}\right)$ artificial cerebral spinal fluid (ACSF) containing (in $\mathrm{mm}$ ) $\mathrm{NaCl}$, $130 ; \mathrm{KCl}, 3.5 ; \mathrm{CaCl}_{2}, 1.2 ; \mathrm{MgSO}_{4}, 1.2 ; \mathrm{NaH}_{2} \mathrm{PO}_{4}, 1.25 ; \mathrm{NaHCO}_{3}, 24 ;$ and dextrose, 10 ; aerated with $95 \% \mathrm{O}_{2}, 5 \% \mathrm{CO}_{2}$ to maintain a nominal $\mathrm{pH}$ of 7.4 (294 $\pm 1 \mathrm{mOsm})$. Several slices were transferred immediately to each well of an "Oslo"-type dual-well interface chamber into which flowed control ACSF at $\sim 1 \mathrm{ml} / \mathrm{min}$. The same humidified $\mathrm{O}_{2} / \mathrm{CO}_{2}$ gas mixture used to oxygenate the ACSF flowed through the air space above the slices in each well. Sliccs wcrc kcpt at $35^{\circ} \mathrm{C}$ and allowed to recover for $90 \mathrm{~min}$ prior to any experimental treatment. The $\mathrm{pH}$ of the experimental ACSF was adjusted by adding several drops of concentrated $\mathrm{HCl}$ or $\mathrm{NaOH}$ and measured with a Beckmann $\phi 21 \mathrm{pH}$ meter. ACSF osmolarity was measured with a freezing-point depression osmometer. Acid-induced changes in ACSF $\left[\mathrm{Ca}^{2+}\right]$ were monitored in some experiments with calcium microelectrodes. ACSF osmolarity was unaffected by $\mathrm{HCl}$ addition but was markedly increased after the addition of $\mathrm{NaOH}$. In these "alkaline" experiments, [ $\mathrm{NaCl}]$ was reduced by $20 \mathrm{~mm}$ in order to maintain osmolarity at a final $\mathrm{pH}$ of 7.7 (298 $\pm 2 \mathrm{mOsm})$; control slices were exposed to ACSF in which $20 \mathrm{mM} \mathrm{NaCl}$ was replaced with $13.3 \mathrm{mM} \mathrm{Na}_{2} \mathrm{SO}_{4}(288 \pm 1 \mathrm{mOsm})$.

Extracellular recordings. Double-barrel $\mathrm{H}^{+}-$and $\mathrm{Ca}^{2+}$-selective microelectrodes (combined tip diameter of 4-7 $\mu \mathrm{m}$ ) were prepared from $1.5 \mathrm{~mm}$ capillary glass tubing using a vertical Narishige electrode puller. The tip of the ion-selective barrel was silanized with $5 \%$ tri- $N$-methyl- chlorosilane (Sigma, St. Louis, MO) in xylene and filled with the appropriate ion-selective resin (Fluka, Ronkonkoma, NY) to a column height of $600-900 \mu \mathrm{m}$. Ion-selective barrels were back-filled with either phosphate-buffered saline, $\mathrm{pH} 7.0\left(\mathrm{H}^{+}\right.$electrode $)$or $1.2 \mathrm{mM} \mathrm{CaCl} / 150$ $\mathrm{mm} \mathrm{NaCl}\left(\mathrm{Ca}^{2+}\right.$ electrode). The reference barrel was filled with $150 \mathrm{~mm}$ $\mathrm{NaCl}$ and used to record both $\mathrm{DC}\left(V_{o}\right)$ changes and evoked field potentials. Microelectrodes were connected to a differential amplifier via high-impedance head stages and were calibrated before and immediately after each experiment. $\mathrm{H}^{+}$electrodes exhibited responses of $50-59 \mathrm{mV} /$ $\mathrm{pH}$ unit while $\mathrm{Ca}^{2+}$ electrodes had slopes of $25-28 \mathrm{mV} /$ decade. Electrodes were first positioned in the bath $\left(\mathrm{pH}=7.4 ;\left[\mathrm{Ca}^{2+}\right]=1.2 \mathrm{~mm}\right)$ to obtain a reference $\mathrm{pH}$ or $\left[\mathrm{Ca}^{2+}\right]$, against which subsequent ion measurements were compared after repositioning in CAl (str. pyramidale). In some experiments $\left[\mathrm{Ca}^{2+}\right]_{o}$ recordings were made in str. radiatum of CA1. Electrode depth was adjusted to maximize the amplitude of the orthodromic response evoked by electrical stimulation $(10-100 \mu \mathrm{A}, 0.15$ $\mathrm{msec}$ ) of the Schaffer-collateral-commissural bundle using an insulated monopolar stimulating electrode. Slices displaying either multiple population spikes or single spikes of $<5 \mathrm{mV}$ were excluded. Evoked potentials were monitored on an oscilloscope and digitized for later computer analysis ( $\Lambda$ itken, 1985); $V_{o}$ and ion signals were recorded on a polygraph and on videotape using a VHS recorder.

Experimental treatments. Evoked waveforms were recorded from all slices in both wells of the chamber. One slice in each well was then selected randomly for continuous $V_{o}$ and ion recording. Control ACSF in one well was then switched to experimental acidic or alkaline ACSF. After slice $\mathrm{pH}_{o}$ had equilibrated with the new $\mathrm{pH}$ of the bath, slices in both wells were made hypoxic by replacing the gas phase with $95 \% \mathrm{~N}_{2}$, $5 \% \mathrm{O}_{2}$. Two experimental paradigms were used. In one, slices were exposed to a constant $8 \mathrm{~min}$ period of hypoxia, a duration that had been empirically determined to result in partial recovery of the orthodromic population spike. In the second paradigm, hypoxia was extended for $5 \mathrm{~min}$ after the negative $V_{o}$ shift occurred in order to subject CA1 neurons to a constant period of HSD. Following hypoxia, both oxygen and control ACSF ( $\mathrm{pH}$ 7.4) were restored. Two hours later, electrophysiological recovery was measured. Evoked potentials in the remain- 
ing slices were recorded from the same approximate position and depth determined at the beginning of the experiment.

Data analysis. For each slice, the ratio of the posthypoxic to pretreatment orthodromic population spike was used as a measure of functional recovery. Spike amplitude was measured from the negative peak to the midpoint of a line connecting the two shoulders of the positive wave. HSD latency was calculated from the time nitrogen was introduced to the point at which the negative $V_{o}$ shift occurred and its duration measured from this negative shift to the point where oxygen was restored. Statistical comparisons were made either by Student's $t$ test or by analysis of variance followed by a Fisher PLSD or Scheffe's $F$ test. All data are presented as mean \pm SEM.

\section{Results}

Manipulation and measurement of slice $p H_{\mathrm{o}}$

Depending on the electrode depth, interstitial $\mathrm{pH}$ was $0.1-0.25$ $\mathrm{pH}$ unit more acidic than the surrounding bath. $\mathrm{A} \mathrm{pH}_{o}$ gradient existed in the upper layers of the slices, reaching a nadir of 7.15 $\pm 0.01(n=14)$ at a depth of $150 \mu \mathrm{m}$, below which no further decrease in $\mathbf{p H}_{o}$ was seen (not shown). Maximal evoked potentials were typically found at depths of $40-80 \mu \mathrm{m}$, corresponding to $\mathrm{pH}_{o}$ of $7.23 \pm 0.01$. During exposure to acidic or alkaline ACSF, slices reached a stable $\mathrm{pH}_{o}$ within 35-45 min; changes in $\mathrm{pH}_{o}$ closely paralleled changes in bath $\mathbf{p H}$ (Fig. 1). No detectable $V_{o}$ changes occurred during this period.

\section{Effects of hypoxia on slice $\mathrm{pH}_{\mathrm{o}}$}

Regardless of the initial direction of the $\mathrm{pH}_{o}$ shift during experimental ACSF treatment, all slices became markedly more acidotic during hypoxia (Figs. 1, 2). This acidification was typically punctuated by a transient alkalinization coincident with the negative $V_{o}$ shift (Fig. 2), as described previously (Kraig et al., 1983). However, slices exposed to the most acidic ACSF ( $\mathrm{pH}$ 6.9) failed to exhibit any sudden $V_{o}$ change or an abrupt alkaline shift (Fig. 2D). Interstitial pH always reached its nadir within $8 \mathrm{~min}$ and typically earlier. Following reoxygenation, slice $\mathrm{pH}_{o}$ gradually returned to its pretreatment level regardless of the experimental ACSF pH, the duration of hypoxia, or the degree of acidification during hypoxia (Figs. 1, 2). However, the lime needed for $\mathrm{pH}_{o}$ recovery was generally longer in the more acidic slices.

\section{Effects of $p H_{0}$ on neuronal excitability}

Under normoxic conditions, acid exposure caused a reversible dose-dependent depression of the population spike $[-10 \pm 3 \%$ $(n=10 ; \Delta \mathrm{pH}=-0.1)$ to $-58 \pm 7 \%(n=12 ; \Delta \mathrm{pH}=-0.5)]$ (Fig. 3). In contrast, mild alkalinity increased the size of the population spike $[+37 \pm 13 \%,(n=5 ; \Delta \mathrm{pH}=+0.3)]$ and occasionally led to the appearance of a smaller secondary spike at higher stimulus intensities. These alkaline-induced changes were not due to the slightly reduced $\left[\mathrm{Cl}^{-}\right]$as they wcre not observed when $20 \mathrm{~mm} \mathrm{NaCl}$ was substituted with $13.3 \mathrm{~mm} \mathrm{Na}_{2} \mathrm{SO}_{4}$ (data not shown).

\section{Effects of $\mathrm{pH}_{\mathrm{o}}$ on neuronal recovery}

In control slices, functional recovery was discontinuous with respect to the duration of $\mathrm{HSD}$, declining sharply to zero as this interval exceeded 250-300 sec (Fig. 4). Following exposure to a fixed $8 \mathrm{~min}$ period of hypoxia (see Materials and Methods), control slices exhibited a mean recovery of $39 \pm 6 \%$ while slices made slightly acidic before hypoxia showed nearly complete recovery (Fig. $5 A$ ). This protective effect was readily seen after reducing the prehypoxic $\mathrm{pH}$ by as little as $0.1 \mathrm{pH}$ unit. In a
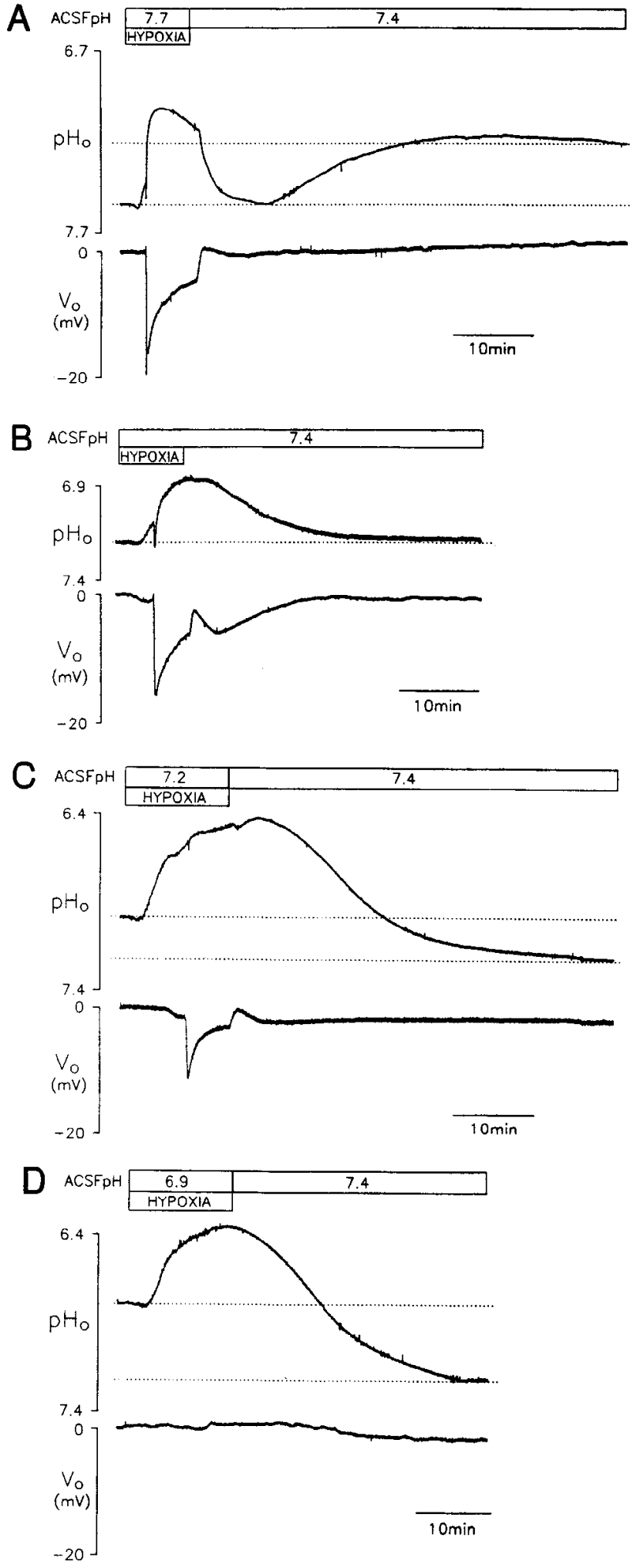

Figure 2. Representative $\mathrm{pH}_{o}$ and $\mathrm{V}_{o}$ recordings in slices made hypoxic during exposure to $\mathrm{pH} 7.7(A), 7.4(B), 7.2(C)$, or $6.9(D)$. Note the increase in HSD latency and the decrease in $\Delta V_{o}$ with declining $\mathrm{pH}_{o}$, as well as the absence of HSD in the most acidic slice $(D)$.

separate set of experiments, slices were exposed to a constant 5 min period of HSD (see Materials and Methods); acid-treated slices were therefore exposed to a longer total period of hypoxia than control slices, given their greater HSD latencies. These 

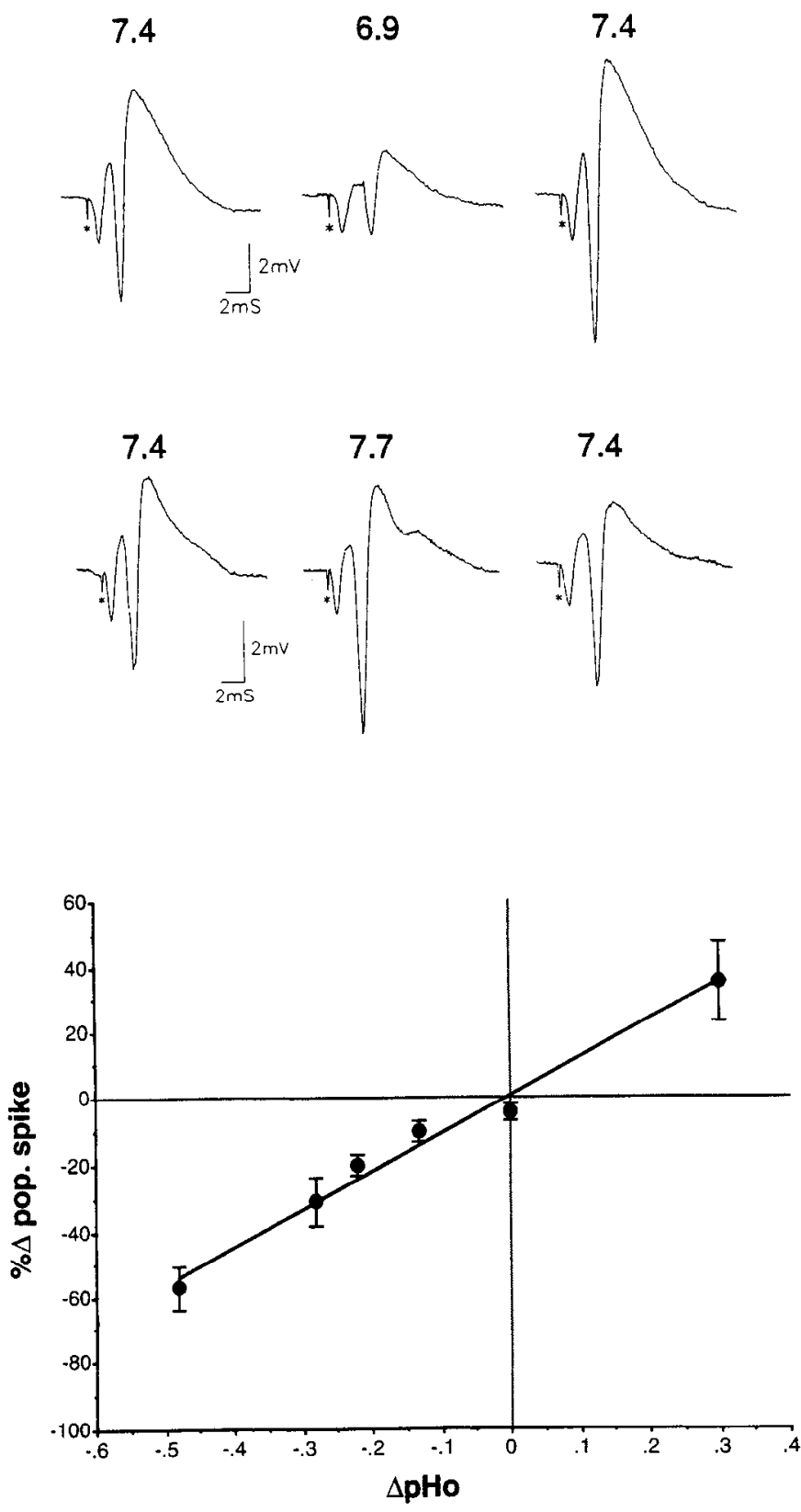

Figure 3. Mild acidosis reversibly depresses while mild alkalinity reversibly enhances neuronal excitability $(n \geq 5)$. Maximal evoked potentials were recorded before, during, and $2 \mathrm{hr}$ after exposure to either $\mathrm{pH} 6.9$ or $\mathrm{pH} 7.7$ ACSF. The asterisks denote stimulation artifacts. The graph summarizes the maximal change in population spike as a function of extracellular $\mathrm{pH}(\mathrm{pHo})$. Errors associated with $\mathrm{pH}_{o}$ measurements were less than $1 \%$ and have been omitted for clarity.

acid-treated slices exhibited improved recovery over controls, though this effect did not reach statistical significance until the prehypoxic $\mathrm{pH}$ had been reduced by $0.3 \mathrm{pH}$ units (Fig. $5 B$ ). Slices treated with $\mathrm{pH}$ 6.9 ACSF, which did not show HSD, were exposed to a period of hypoxia nearly twice that of controls (15 min) and yet showed significantly better recovery (73 \pm $12 \% ; p<0.01, n=7$ ). Surprisingly, alkaline-treated slices (ACSF $\mathrm{pH}=7.7$ ) and their matching $\mathrm{Na}_{2} \mathrm{SO}_{4}$-treated controls (ACSF $\mathrm{pH}=7.4$ ) showed similar recovery after $8 \mathrm{~min}$ of hypoxia [83 $\pm 9 \%(\mathrm{pH} 7.4)$ vs $77 \pm 9 \%(\mathrm{pH} \mathrm{7.7)} ; n=12]$, recoveries that were also significantly greater $(p<0.01)$ than seen in normal ACSF-treated slices $(39 \pm 6 \%)$. Alkaline slices also required a longer period of $\mathrm{HSD}$ ( $>5 \mathrm{~min}$ ) to exhibit any measurable injury; however, after HSD duration was extended to $7 \mathrm{~min}$, their recovery did not differ significantly from that of matching $\mathrm{Na}_{2} \mathrm{SO}_{4}$ treated controls $[50 \pm 11(\mathrm{pH}=7.4)$ vs $49 \pm 14(\mathrm{pH}=7.7)$; $n=3]$.

\section{Effects of $p H_{\mathrm{o}}$ on $H S D$ latency and $\Delta V_{\text {。 }}$}

In control slices, HSD occurred with a latency of $212 \pm 8 \mathrm{sec}$ and a $V_{o}$ shift of $-15 \pm 1 \mathrm{mV}$. Mild acidification of slices prior to hypoxia led to a dose-dependent increase in the latency of HSD during hypoxia, as well as a significant blunting of the negative DC shift (Fig. 6). Slices exposed to the most acidic ACSF ( $\mathrm{pH}$ 6.9) never exhibited HSD even when the duration of hypoxia was extended to $15 \mathrm{~min}$ (Fig. $2 D$ ). In contrast, pretreatment with alkaline ACSF ( $\mathrm{pH} 7.7$ ) both shortened HSD latency and increased the size of the negative $V_{o}$ shift (Fig. 6).

\section{Effects of $\mathrm{pH}_{\mathrm{o}}$ on $\left[\mathrm{Ca}^{>+}\right]_{\mathrm{o}}$ during hypoxia}

Acidification of the ACSF to $\mathrm{pH} 7.1$ led to a gradual increase in the $\left[\mathrm{Ca}^{2+}\right]_{o}$ in str. pyramidale from $1.20 \pm 0.01$ to $1.32 \pm$ 0.01 (Table 1), as measured with $\mathrm{Ca}^{2+}$ microelectrodes (Balestrino and Somjen, 1988). An identical prehypoxic rise in bath $\left[\mathrm{Ca}^{2+}\right]$ was detected during acid treatment $(n=12 ; p<0.01)$. During hypoxia, no consistent changes in $\left[\mathrm{Ca}^{2+}\right]_{0}$ occurred in either group prior to HSD. During a fixed $5 \mathrm{~min}$ period of HSD, $\left[\mathrm{Ca}^{2+}\right]_{0}$ fell precipitously in both groups and remained below pre-HSD levels for the duration of hypoxic exposure (Fig. 7). Both groups exhibited an identical decrease in $\left[\mathrm{Ca}^{2+}\right]_{0}$ during HSD: $1.05 \pm 0.02(\mathrm{pH} \mathrm{7.4)}$ versus $1.05 \pm 0.03(\mathrm{pH} \mathrm{7.1)}, n=$ 13 (Table 1). Similar results were obtained in str. radiatum ( $n$ $=6$ ). Upon reoxygenation, a significant shortening of the $\left[\mathrm{Ca}^{2+}\right]_{0}$ recovery time was observed in str. radiatum in the acid-treated slices, though this effect failed to reach statistical significance in str. pyramidale (Table 1).

\section{Discussion}

The cardinal findings of this study are that mild acidosis delays HSD (anoxic depolarization) and improves posthypoxic recovery of synaptic transmission in hippocampal slices. Earlier studies carried out in the presence of elevated lactic acid (Schurr et al., 1988a) revealed a similar paradoxical improvement in hypoxic slice recovery, but HSD latency was not measured. Moreover, the subsequent finding that lactate itself can be utilized as an alternative substrate in energy-deprived tissue (Schurr et al., $1988 \mathrm{~b}$ ) has served to deemphasize low $\mathrm{pH}$ as a protective agent. The present study resurrects the putative role of mild acidosis as an endogenous neuroprotectant during hypoxia (Giffard et al., 1990a; Tombaugh and Sapolsky, 1990a,b) and demonstrates that this protection is due in part to the ability of low $\mathrm{pH}$ to delay the onset of HSD. This study also strengthens earlier work that first suggested a causal relationship between HSD duration and hypoxic neuronal injury in vitro (Balestrino and Somjen, 1986).

In agreement with other reports, resting $\mathrm{pH}_{o}$ in control slices was found to be slightly more acidic than the surrounding bath (Balestrino and Somjen, 1988; Walz, 1989; Chen and Chesler, 1992 ), and $\sim 0.1 \mathrm{pH}$ unit more acidic than interstitial $\mathrm{pH}$ values commonly reported in vivo (cf. Chesler, 1990). Reducing $\mathbf{p H}_{o}$ further reversibly depressed the evoked population spike, while elevating $\mathrm{pH}_{\circ}$ had the opposite effect. Similar changes in hippocampal excitability have been seen by others, both in vitro and in vivo (Balestrino and Somjen, 1988; Walz and Harold, 


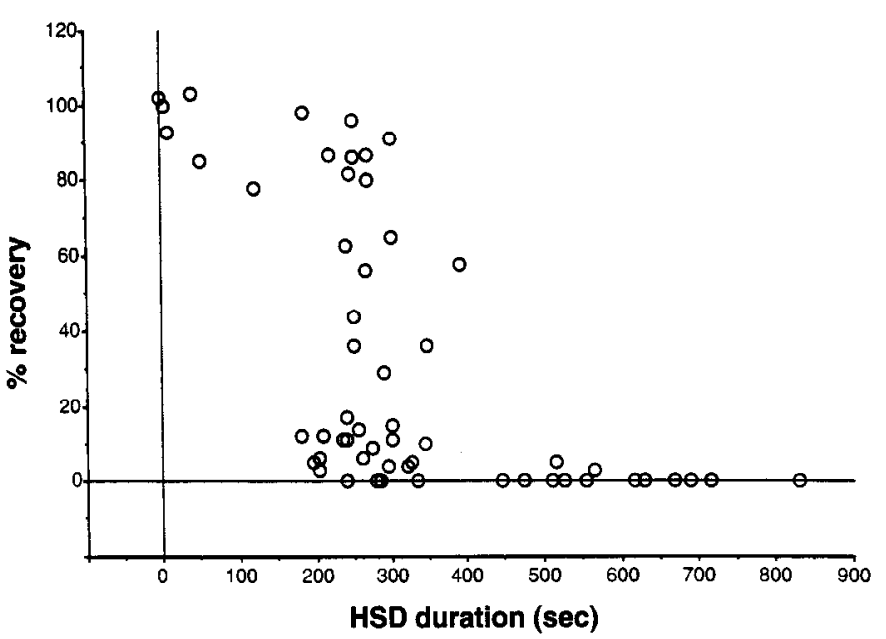

Figure 4. Hypoxic neuronal injury occurs after cells undergo a critical period of HSD. Data were obtained from control slices (ACSF pH = 7.4) exposed to varying hypoxic periods.

1989; Krnjevic and Walz, 1990). Except for certain cells in the brainstem and spinal cord, acidosis appears to depress the excitability of a majority of central neurons (Meyer et al., 1961; Speckman and Caspers, 1974; Jarolimek et al., 1990).

In acid-treated slices, reduced HSD duration was associated with improved neuronal recovery, supporting a causal link between HSD and hypoxic neuronal injury (Balestrino and Somjen, 1986; Nedergaard and Diemer, 1987; Gill et al., 1992; Ijjima et al., 1992; Chen et al., 1993). Moreover, slices subjected to the most severe acidosis failed to undergo HSD and exhibited improved recovery even after the hypoxic period had been nearly doubled. This indicates (1) that the duration of hypoxia in hippocampal slices does not necessarily predict neuronal recovcry, and (2) that extracellular acidosis comparable in both duration and degree to that seen during transient ischemia in vivo (Siemkowicz and Hansen, 1981) does not necessarily aggravate hypoxic neuronal injury in vitro. In control slices, a discontinuous relationship emerged between HSD duration and recovery, indicating that neuronal injury evolved once a critical period $(\sim 250-300 \mathrm{sec})$ of depolarization had been reached (Fig. 4). By delaying HSD, even very mild acid treatments could reduce HSD duration below this threshold, thereby promoting neuronal recovery.

One possible explanation for the pH effect on HSD latency may be related to changes in cell excitability. During hypoxia, hippocampal neurons undergo a transient period of spontaneous hyperexcitability prior to HSD (Sick et al., 1987; Hershkowitz et al., 1993), and a variety of agents capable of blocking synaptic transmission or cell excitability have been shown to delay HSD (Aitken et al., 1991; Jing et al., 1993). Because ATP consumption rises with increased neuronal activity (cf. Erecinska and Silver, 1989), increased miniature EPSC frequency might enhance energy demand at a time when ATP supply is severely limited, somehow accelerating the opening of membrane channels that underlie HSD. By depressing cell excitability, low $\mathrm{pH}_{o}$ may have helped maintain ATP levels and transmembrane ion gradients, thereby delaying HSD. In support of this, hypoxic CA1 neurons experience more rapid energy failure and undergo HSD sooner than the less excitable dentate granule cells (Jefferys and Haas, 1982; Balestrino et al., 1989; Kass and Lipton, 1989).

\section{A: Fixed Duration of Hypoxia}

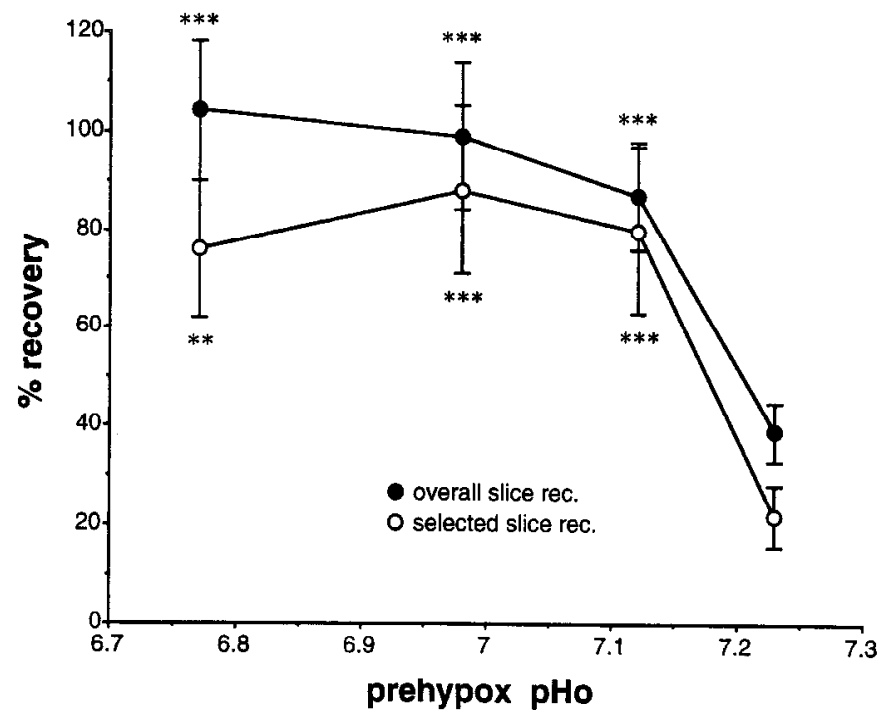

\section{B: Fixed Duration of HSD}

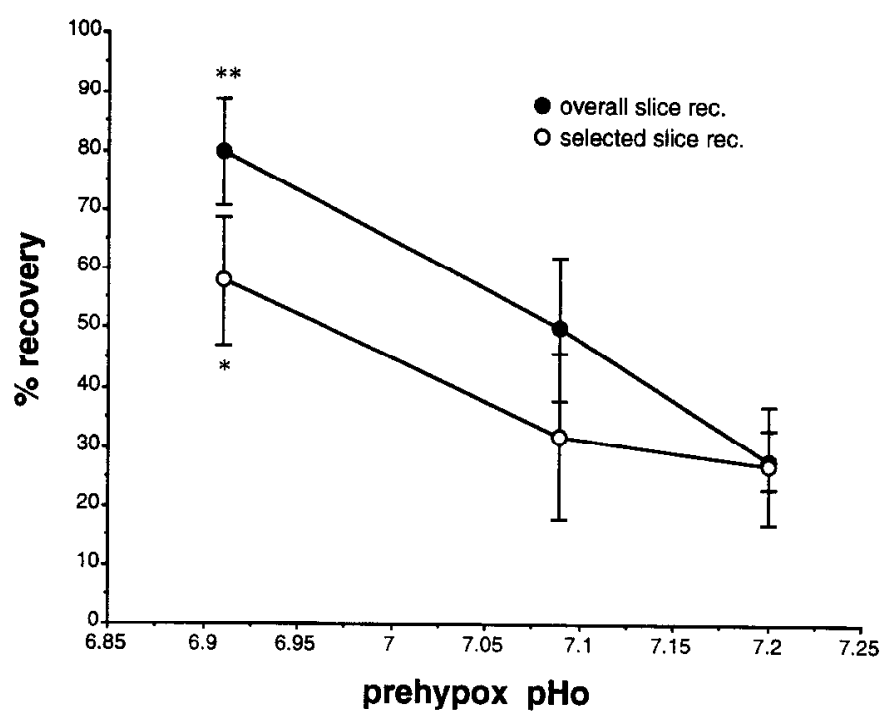

Figure 5. Mild acidosis improves neuronal recovery following a fixed $(8 \mathrm{~min})$ period of hypoxia $(A)$ and after a fixed $(5 \mathrm{~min})$ period of HSD $(B)$. The recovery of selected slices in which $V_{o}$ was monitored $(n \geq 6$; O) and the pooled recoveries of all slices $(n \geq 15$; $\theta)$ are plotted separately. The errors associated with the prehypoxic $\mathrm{pH}_{o}$ measurements were less than $1 \%$ and have been omitted for clarity. *, significantly different from control (ACSF $\mathrm{pH}=7.4$ ), $p<0.05$; **, significantly different from control (ACSF $\mathrm{pH}=7.4), p<0.01$; $^{* * *}$, significantly different from control (ACSF $\mathrm{pH}=7.4), p<0.001$.

Also, glucose supplementation delays HSD (Hansen, 1978), while hypothermia, which is capable of slowing hypoxic ATP depletion (Welsh et al., 1990; Katsura et al., 1992), both delays HSD and reduces its frequency during ischemia (Nedergaard and Diemer, 1987; Katsura et al., 1992; Chen et al., 1993; Taylor and Wcbcr, 1993). Indecd, HSD has been associated with a threshold of energy failure (Ekholm et al., 1993).

The proximal cause of HSD is not known. Several studies have implicated the excitatory amino acid glutamate (Van Har- 
Figure 6. Mild acidosis increases HSD latency and reduces the sizc of the ncgative $\mathrm{V}_{\mathrm{o}}$ shift. In both cases, mild alkalosis has the opposite effect $(n \leq 5)$. *, significantly different from control $(\mathrm{ACSF} \mathrm{pH}=7.4), p<0.05{ }^{* *}$, significantly different from control (ACSF pH $=7.4), p<0.01 ;{ }^{* * *}$, significantly different from control (ACSF $\mathrm{pH}=7.4)$, $p<0.001$.

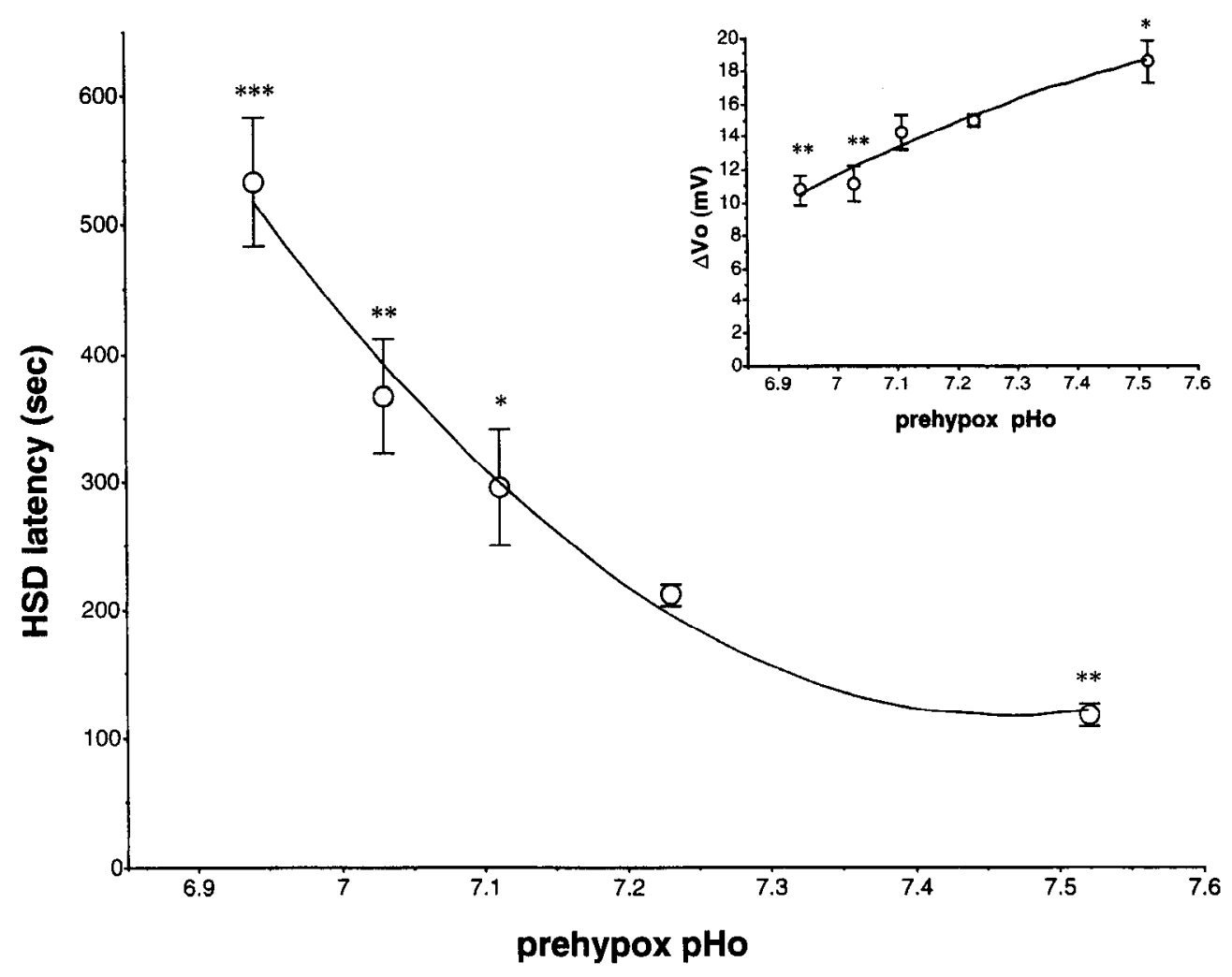

reveld, 1959; Bures et al., 1974), but its role in HSD remains controversial (Hernandez-Caceres et al., 1987; Aitken et al., 1988; Silver and Erecinska, 1990; Lauritzen and Hansen, 1992). Reduced $\mathrm{pH}_{o}$ may have delayed HSD by blunting NMDA receptor activity (Tang et al., 1990; Traynalis and Cull-Candy, 1990; Jing et al., 1993); however, HSD was significantly delayed when the ACSF pH was reduced by as little as $0.1 \mathrm{pH}$ unit, resulting in a $\mathrm{pH}_{o}$ during $\mathrm{HSD}(6.82 \pm 0.02)$ capable of causing only partial NMDA receptor blockade (Tang et al., 1990). Thus, either HSD onset in acid-treated slices was very sensitive to small reductions in NMDA receptor activity, or it was delayed by additional or alternative factors. In either case, $\mathrm{H}^{+}$-mediated suppression of NMDA receptor-mediated $\mathrm{Ca}^{2+}$ influx was probably not involved, as lowering $\left[\mathrm{Ca}^{2+}\right]_{o}$ actually accelerates $\mathrm{HSD}$ onset in vitro (Young et al., 1991; Mitani et al., 1993).
During HSD, neurons undergo a dramatic rise in intracellular $\mathrm{Ca}^{2+}$ (Silver and Erecinska, 1990; Mitani et al., 1993), and reducing extracellular $\mathrm{Ca}^{2+}$ enhances posthypoxic neuronal recovery in hippocampal slices (Balestrino and Somjen, 1986; Amagasa et al., 1990; Young et al., 1991). Agents that delay HSD (and thus shorten its duration) are thought to protect neurons both in vitro and in vivo by limiting the period during which intracellular calcium remains elevated (Balestrino and Somjen, 1986; Young et al., 1991; Gill et al., 1992; lijima et al., 1992; Gido et al., 1993). Results from the present study imply that $\left[\mathrm{Ca}^{2+}\right]_{i}$ must remain elevated for a certain period, given that neuronal recovery fell sharply after a critical duration of HSD had been reached. It seems unlikely that acid exposure improved recovery by curtailing $\mathrm{Ca}^{2+}$ influx durinr $\mathrm{HSD}$, as reduced $\mathrm{pH}_{o}$ failed to blunt the dramatic fall in $\left[\mathrm{Ca}^{\dot{ }+}\right]_{0}$ during HSD. Thus,

\begin{tabular}{|c|c|c|c|c|c|c|}
\hline $\begin{array}{l}\text { ACSF } \\
\mathrm{pH}\end{array}$ & $\mathbf{p H}_{o}(\mathrm{HSD})$ & Prehypox. & $\begin{array}{l}{\left[\mathrm{Ca}^{2+}\right]_{o}(\mathrm{~mm})} \\
\mathrm{HSD}\end{array}$ & Posthypox. & $\Delta\left[\mathrm{Ca}^{2+}\right]_{o}$ & $\begin{array}{l}{\left[\mathrm{Ca}^{2+}\right]_{o}} \\
\text { recovery time } \\
\text { (min) }\end{array}$ \\
\hline \multicolumn{7}{|c|}{ Str. pyramidale } \\
\hline 7.4 & $7.08 \pm 0.01$ & $1.20 \pm 0.01$ & $0.15 \pm 0.02$ & $1.19 \pm 0.01$ & $1.05 \pm 0.02$ & $28 \pm 3$ \\
\hline 7.1 & $6.53 \pm 0.13^{* * *}$ & $1.32 \pm 0.01^{* *}$ & $0.26 \pm 0.03^{* *}$ & $1.21 \pm 0.02$ & $1.05 \pm 0.03$ & $20 \pm 4$ \\
\hline \multicolumn{7}{|c|}{ Str. radiatum } \\
\hline 7.4 & - & $1.24 \pm 0.01$ & $0.15 \pm 0.05$ & $1.24 \pm 0.02$ & $1.09 \pm 0.05$ & $24 \pm 3$ \\
\hline 7.1 & - & $1.49 \pm 0.02^{* *}$ & $0.34 \pm 0.12^{* *}$ & $1.25 \pm 0.02$ & $1.16 \pm 0.10$ & $11 \pm 3^{*}$ \\
\hline
\end{tabular}




\section{Str. pyramidale}

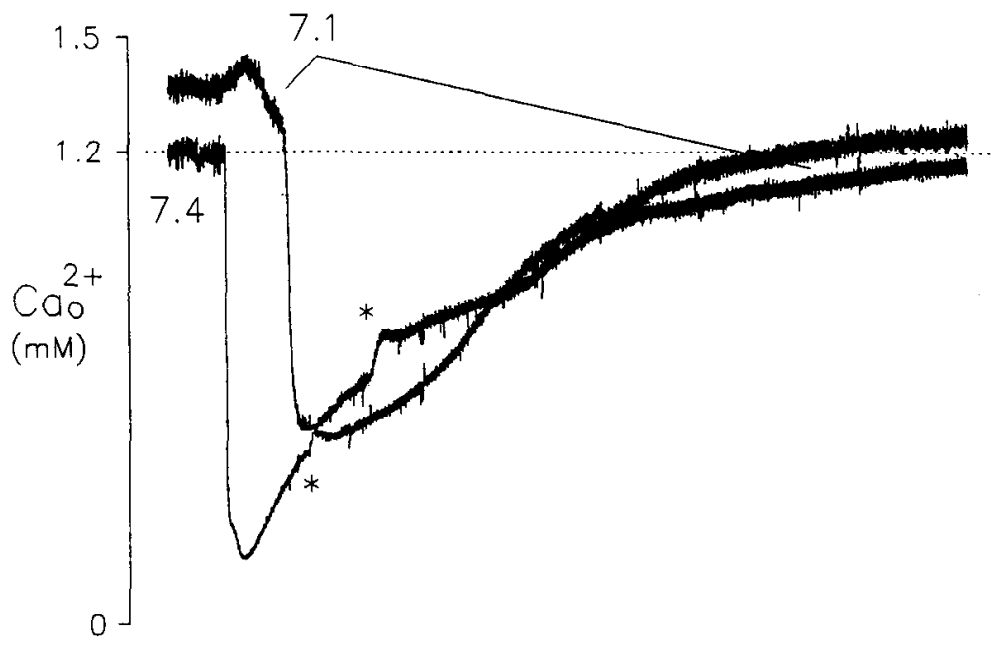

\section{Str. radiatum}

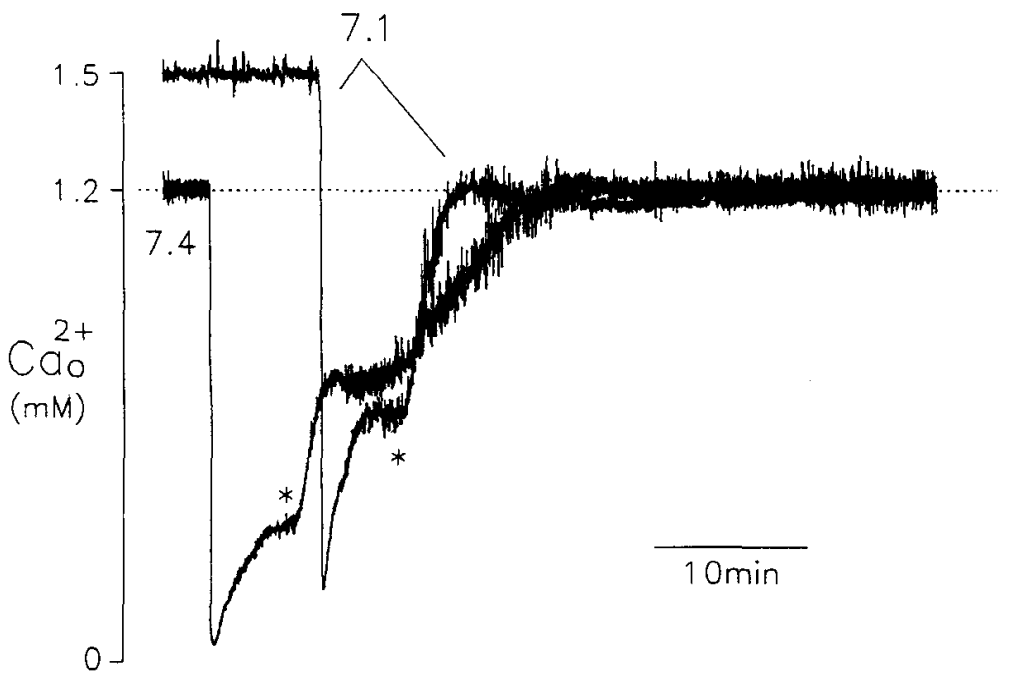

\begin{abstract}
Figure 7. Mild acidosis does not affect the decrease in extracellular calcium during HSD but accelerates its posthypoxic recovery: representative $\left[\mathrm{Ca}^{2+}\right]_{0}$ recordings from str. pyramidale or str. radiatum (CA1) in separate pairs of slices subjected to $5 \mathrm{~min}$ of HSD during exposure to either $\mathrm{pH} 7.4$ or 7.1 . Acidtreated slices were returned to normal $\operatorname{ACSF}(\mathrm{pH}=7.4)$ immediately upon reoxygenation (asterisks). The onset of hypoxia coincides with the beginning of each recording, though a longer hypoxic exposure was used in the acid-treated slices to elicit an identical period of HSD. Note the elevated prehypoxic $\left[\mathrm{Ca}^{2+}\right]_{o}$, its delayed decline, and its accelerated recovery (str. radiatum) in the acid-treated slice.
\end{abstract}

in slices exposed to a fixed period of hypoxia, mild acidity probably improved neuronal recovery by shortening the duration of $\mathrm{Ca}^{2+}$ overload rather than by reducing the net $\mathrm{Ca}^{2+}$ influx during HSD.

In slices exposed to a fixed period of HSD, the mechanism of protection afforded by low $\mathrm{pH}$ is less obvious but may also be related to a reduced duration of $\mathrm{Ca}^{2+}$ overload, as suggested by the accelerated posthypoxic recovery of $\left[\mathrm{Ca}^{2+}\right]_{0}$ (see Table 1). These findings are consistent with reports that the neuroprotective action of low $\mathrm{pH}_{o}$ in vitro is not limited to NMDAreceptor blockade (Tombaugh and Sapolsky, 1990a, 1993; Kaku et al., 1993) and clearly demonstrate that the beneficial action of low $\mathrm{pH}_{o}$ extends beyond its ability to delay HSD.

It should be emphasized that although a rise in $\left[\mathrm{Ca}^{2+}\right]_{i}$ occurs simultaneously with a fall in $\left[\mathrm{Ca}^{2+}\right]_{u}$ during HSD (Silver and Erecinska, 1990), $\mathrm{Ca}^{2+}$ influx sufficient to raise cytosolic calcium significantly prior to HSD could have escaped detection, especially in the distal dendrites. Also, a rise in $\left[\mathrm{Ca}^{2+}\right]_{i}$ due to its release from intracellular pools (Mitani et al., 1993) would have been undetectable. If acid treatment enhanced intracellular acidosis during hypoxia, this potentially could have increased $\left[\mathrm{Ca}^{2+}\right]_{i}$, either by enhancing releasc from intracellular stores via $\mathrm{H}^{+} / \mathrm{Ca}^{2+}$ exchange or by reducing intracellular $\mathrm{Ca}^{2+}$ buffering (Moody, 1984). Such mechanisms may underlie the recent finding that reduced $\mathrm{pH}_{o}$ enhanced $\left[\mathrm{Ca}^{2+}\right]_{i}$ during hypoxia in cortical slices (O'Donnell and Bickler, 1994), further supporting the view that low $\mathrm{pH}$ improved neuronal recovery in ways other than simply blunting the size of the calcium signal.

The neuroprotective effects of $\mathrm{pH}_{o}$ reported here do not exclude the possibility that they resulted from actions mediated "downstream" of hypoxic calcium accumulation. As an example, the affinity of calmodulin for $\mathrm{Ca}^{2+}$ falls dramatically as 
$\mathrm{pH}$ drops, potentially affecting critical second-messenger systems that mediate neuronal injury (Tkachuk and Men'shikov, 1981; Busa and Nuccitelli, 1984; Chetkovitch et al., 1991). Also, certain $\mathrm{Ca}^{2+}$-sensitive enzymes may themselves be $\mathrm{pH}$ sensitive. In addition, ischemia-induced depression of protein synthesis has been linked to $\mathrm{Ca}^{2+}$ influx (Widmann et al., 1991), and such depression can be attenuated by mild acidosis in vitro (K. RaleySusman, personal communication). However, whether $\mathrm{pH}_{o}$ manipulation in the present study influenced $\mathrm{HSD}$ latency, $\mathrm{Ca}^{2+}$ homeostasis, or neuronal recovery via changes in neuronal $\mathbf{p H}_{i}$ remains speculative. Several groups have reported a fall in $\mathbf{p H}_{i}$ in response to low $\mathrm{pH}_{o}$ (Whittingham et al., 1989; Ou-yang et al., 1993; O'Donnell and Bickler, 1994), but the influence of extracellular acidity on neuronal $\mathrm{pH}_{i}$ in adult hypoxic brain tissue has not been characterized.

Because acidosis clearly protected against hypoxic injury, mild alkalosis was expected to worsen cell recovery (Giffard et al., 1992). Alkaline treatment did acceleratc HSD onsct but failed to exacerbate injury relative to $\mathrm{Na}_{2} \mathrm{SO}_{4}$-treated controls. $\mathrm{Be}$ cause the difference in HSD duration between these two groups became smaller as the total hypoxic duration was increased, this may have obscured any difference in neuronal recovery. In addition, damaging mechanisms triggered by hypoxia may have been maximally activated at $\mathrm{pH} 7.4$, preventing a further increase at pH 7.7.

The consequence of $\mathrm{pH}$ shifts during hypoxic insults in vivo is controversial, and there are obvious limitations about extending in vitro findings to the intact animal. For example, certain pathological events potentially aggravated by acidosis in situ, such as edema and vascular damage (Paljarvi et al., 1983; Smith and Siesjo, 1986), are absent in tissue slices. Glucose, lactate, and $\mathrm{CO}_{2}$ concentrations change dramatically in situ but were not adjusted in this study. Moreover, rapid functional failurc in hypoxic slices is not necessarily equivalent to ischemic neuronal necrosis in vivo. Nevertheless, several implications for ischemic injury do arise from this study. The degree of acidification during transient global ischemia may dictate the latency of HSD, while the protective effects of lingering acidosis during reperfusion may offset some of the damaging biochemical cascades that trigger delayed neuronal necrosis. In addition, moderate but persistent acidosis in the peri-infarct zone may reduce the frequency of potentially damaging SDs. In support of this, Simon et al. (1993) have reported that hypercarbic ventilation can reduce infarction volume in focally ischemic rats.

In sum, this study characterizes a neuroprotective effect of mild acidosis in hypoxic hippocampal slices. This effect was associated with a shortening of HSD duration and involved at least one additional neuroprotective mechanism apparently unrelated to the increase in intracellular calcium during HSD. The exact nature of neuronal injury in the ischemic brain undoubtedly differs from that in tissue slices, but some overlap of the damaging cascades presumably exists, suggesting that the beneficial effects of acidosis described in this study may occur during hypoxic insults in situ.

\section{References}

Aitken PG, Balestrino M, Somjen GG (1988) NMDA antagonists: lack of protective effect against hypoxic damage in CAl region of hippocampal slices. Neurosci Lett 89:187-192.

Aitken PG, Jing J, Young JN, Somjen GG (1991) Ion channel involvement in hypoxia-induced spreading depression in hippocampal slices. Brain Res 541:7-11.
Amagasa M, Ogawa A, Yoshimoto T (1990) Effects of calcium and calcium antagonists against deprivation of glucose and oxygen in guinea pig hippocampal slices. Brain Res 526:1-7.

Balestrino M, Somjen GG (1986) Chlorpromazine protects brain tissue in hypoxia by delaying spreading depression-mediated calcium influx. Brain Res 385:219-226.

Balestrino M, Somjen GG (1988) Concentration of carbon dioxide, interstitial $\mathrm{pH}$ and synaptic transmission in hippocampal formation of the rat. J Physiol (Lond) 396:247-266.

Balestrino M, Aitken PG, Somjen GG (1989) Spreading depressionlike depolarization in CA 1 and fascia dentata: relationship to selective vulnerability. Brain Res 497:102-107.

Bures J, Buresova O, Krivanek J (1974) The mechanism and applications of Leao's spreading depression of electroencephalographic activity. New York: Academic.

Busa WB, Nuccitelli R (1984) Metabolic regulation via intracellular pH. Am J Physiol 246:R406-R438.

Chen JCT, Chesler M (1992) Modulation of extracellular pH by glutamate and GABA in rat hippocampal slices. J Neurophysiol 67:2936.

Chen Q, Chopp M, Bodzin G, Chen H (1993) Temperature modulation of cerebral depolarization during focal cerebral ischemia in rats: correlation to ischemic injury. J Cereb Blood Flow Metab 13: 389-394.

Chesler M (1990) The regulation and modulation of $\mathrm{pH}$ in the central nervous system. Prog Neurobiol 34:401-427.

Chetkovitch DM, Gray R, Johnston D, Sweatt JD (1991) $N$-methylD-aspartate receptor activation increases cAMP levels and voltagegated $\mathrm{Ca}^{2+}$ channel activity in area CAl hippocampus. Proc Natl Acad Sci USA 88:6467-6471.

Crowell JW, Kaufmann BN (1961) Changes in tissue pH after cardiac arrest. Am J Physiol 200:743-745.

Ekholm A, Katsura K, Siesjo BK (1993) Coupling of energy failure and dissipative $\mathrm{K}^{+}$flux during ischemia: role of pre-ischemic plasma glucose concentration. J Cereb Blood Flow Metab 13:193-200.

Gido G, Katsura K, Kristian T, Siesjo BK (1993) Influence of plasma glucose concentration on rat brain extracellular calcium transients during spreading depression. J Cereb Blood Flow Metab 13:179-182.

Giffard RG, Monyer H, Christine CW, Choi DW (1990a) Acidosis reduces NMDA receptor activation, glutamate neurotoxicity, and oxygen-glucose deprivation neuronal injury in cortical cultures. Brain Res 506:339-342.

Giffard RG, Monyer H, Choi DW (1990b) Selective vulnerability of cultured cortical glia to injury by extracellular acidosis. Brain Res 530:138-141.

Giffard RG, Weiss JH, Choi DW (1992) Extracellular alkalinity exacerbates injury of cultured cortical neurons. Stroke 23:1817-1821.

Gill R, Andiné P, Hillered L, Persson L, Hagberg H (1992) The effect of MK-801 on cortical spreading depression in the penumbral zone following focal ischaemia in the rat. J Cereb Blood Flow Metab 12: 371-379.

Goldman SA, Pulsinelli WA, Clarke WY, Kraig RP, Plum F (1989) The effects of extracellular acidosis on neurons and glia in vitro. $\mathrm{J}$ Cereb Blood Flow Metab 9:471-477.

Hansen AJ (1978) The extracellular potassium concentration in brain cortex following ischemia in hypo-and hyperglycemic rats. Acta Physiol Scand 102:324-329.

Hansen AJ, Nedergaard M (1988) Brain ion homeostasis in cerebral ischemia. Neurochem Pathol 9:195-209.

Hernandez-Caceres J, Macius-Gonzalez R, Brozek G, Bures J (1987) Systemic ketamine blocks cortical spreading depression but does not delay the onset of terminal anoxic depolarization. Brain Res 437:360364.

Hershkowitz N, Katchman AN, Veregge S (1993) Site of synaptic depression during hypoxia: a patch clamp analysis. J Neurophysiol 69:432-441.

Iijima T, Mies G, Hossmann K-A (1992) Repeated negative DC deflections in rat cortex following middle cerebral artery occlusion are abolished by MK-801: effect on volume of ischemic injury. J Cereb Blood Flow Metab 12:727-733.

Jarolimek W, Misgeld U, Lux HD (1990) Neurons sensitive to pH in slices of the rat ventral medulla oblongata. Pflugers Arch Eur J Physiol 416:247-253.

Jefferys JGR, Haas HL (1982) Synchronized bursting of CA1 hippocampal pyramidal cells in the absence of synaptic transmission. Nature 300:448-450. 
Jing J, Aitken PG, Somjen GG (1993) Role of calcium channels in spreading depression in rat hippocampal slices. Brain Res 604:251259.

Kaku DA, Giffard RG, Choi DW (1993) Neuroprotective effects of glutamate antagonists and extracellular acidity. Science 260:15161518.

Kass IS, Lipton P (1989) Protection of hippocampal slices from young rats against anoxic transmission damage is due to better maintenance of ATP. J Physiol (Lond) 413:1-11.

Katsura A, Minamisawa H, Ekholm A, Folbergrova J, Siesjo BK (1992) Changes of labile metabolites during anoxia in moderately hypo- and hyperthermic rats: correlation to membrane fluxes of $\mathrm{K}^{+}$. Brain Res 590:6-12.

Kraig RP, Ferreira-Filho CR, Nicholson C (1983) Alkaline and acid transients in cerebellar microenvironment. J Neurophysiol 49:831850.

Kraig RP, Petito C, Plum F, Pulsinelli WA (1987) Hydrogen ions kill brain at concentrations reached in ischemia. J Cereb Blood Flow Metab 7:379-386.

Krnjevic K, Walz WW (1990) Acidosis and blockade of orthodromic responses caused by anoxia in rat hippocampal slices at different temperatures. J Physiol (Lond) 422:127-144.

Laeo AAP (1944) Spreading depression of activity in cerebral cortex. J Neurophysiol 7:359-390.

Lauritzen M, Hansen AJ (1992) The effect of glutamate receptor blockade on anoxic depolarization and cortical spreading depression. J Cereb Blood Flow Metab 12:223-229.

Ljunggren B, Norberg K, Siesjo BK (1974) Influence of tissue acidosis upon restitution of brain energy metabolism following total ischemia. Brain Res 77:173-183.

Meyer JS, Gotoh F, Tazaki Y (1961) Inhibitory action of carbon dioxide and acetazolamide in seizure activity. Electroencephalogr Clin Neurophysiol 13:762-775.

Mitani A, Yanase H, Kimiko S, Yousuke W, Kataoka K (1993) Origin of intracellular calcium elevation induced by in vitro ischemic-like condition in hippocampal slices. Brain Res 601:103-110.

Moody WJ (1984) Effects of intracellular $\mathrm{H}^{+}$on the electrical properties of excitable cells. Annu Rev Neurosci 7:257-278.

Myers RE (1979) A unitary theory of causation of anoxic and hypoxic brain pathology. Adv Neurol 26:195-213.

Nedergaard M (1987) Transient focal ischemia in hyperglyccmic rats is associated with increased cerebral infarction. Brain Res 408:9785.

Nedergaard M (1988) Mechanisms of brain damage in focal cerebral ischemia. Acta Neurol Scand 77:81-101.

Nedergaard M, Diemer NH (1987) Focal ischemia of the rat brain, with special reference to the plasma glucose concentration. Acta Neuropathol (Berl) 73:131-137.

O'Donnell BR, Bickler PE (1994) Influence of $\mathrm{pH}$ on calcium influx during hypoxia in rat cortical slices. Stroke 25:171-177.

Ou-yang Y, Mellergard P, Siesjo BK (1993) Regulation of intracellular $\mathrm{pH}$ in single rat cortical neurons in vitro: a microspectrofluorometric study. J Cereb Blood Flow Metab 13:827-840.

Paljarvi L, Rhencrona S, Soderfeldt B, Olssen Y, Kalimo H (1983) Brain lactic acidosis and ischemic cell damagc: quantitative ultrastructural changes in capillaries of rat cerebral cortex. Acta Neuropathol (Berl) 60:232-240.

Plum $F$ (1983) What causes infarction in ischemic brain?: the Robert Wartenberg lecture. Neurology 33:222-233.

Roberts EL Jr, Sick TJ (1988) Calcium-sensitive recovery of extracellular potassium and synaptic transmission in rat hippocampal slices exposed to anoxia. Brain Res 456:113-119.

Roberts EL Jr, Sick TJ (1992) Glucose enhances recovery of potassium ion homeostasis and synaptic excitability after anoxia in hippocampal slices. Brain Res 570:225-230.

Schurr A, Dong W-Q, Reid KH, West CA, Rigor BM (1988a) Lactic acidosis and recovery of function following cerebral hypoxia in vitro. Brain Res 438:311-314.

Schurr A, West CA, Rigor BM (1988b) Lactatc supported synaptic function in the rat hippocampal slice preparation. Science 240:13261328.
Sher PK (1990) The effects of acidosis on chronically hypoxic neurons in culture. Exp Neurol 107:256-262.

Sick TJ, Solow EL, Roberts EL Jr (1987) Extracellular potassium ion activity and electrophysiology in the hippocampal slice: paradoxical recovery of synaptic transmission during anoxia. Brain Res 418:227234.

Siemkowicz E, Hansen AJ (1981) Brain extracellular ion composition and EEG activity following 10 minutes ischemia in normo- and hyperglycemic rats. Stroke 12:236-240.

Siesjo BK (1988) Acidosis and ischemic brain damage. Neurochem Pathol 9:31-88.

Silver IA, Erecinska M (1990) Intracellular and extracellular changes of $\left[\mathrm{Ca}^{2+}\right]$ in hypoxia and ischemia in rat brain in vivo. J Gen Physiol 95:837-866.

Simon RP, Niiro M, Gwinn R (1993) Brain acidosis induced by hypercarbic ventilation attenuates focal ischemic injury. J Pharmacol Exp Ther 267:1428-1431.

Smith M-L, Siesjo BK (1988) Acidosis-related brain damage: immediate and delayed events. In: Mechanisms of cerebral hypoxia and stroke (Somjen GG, ed), pp 57-71. New York: Plenum.

Somjen GG, Aitken PG, Czeh GL, Herreras O, Jing J, Young JN (1992) Mechanism of spreading depression: a review of recent findings and a hypothesis. Can J Physiol Pharmacol 70:\$248-\$254.

Speckman E-J, Caspers $\mathrm{H}$ (1974) The effect of $\mathrm{O}_{2}$ - and $\mathrm{CO}_{2}$-tensions in the nervous tissue on neuronal activity and DC potentials. In: Handbook of electroencephalography and clinical neurophysiology, Vol 2, Pt C (Remond A, ed), pp 71-89. New York: Elsevier.

Takadera T, Shimada Y, Mohri T (1992) Extracellular pH modulates $\mathrm{N}$-methyl-D-aspartate mediated neurotoxicity and calcium accumulation in rat cortical cultures. Brain Res 572:126-131.

Tang C, Dichter M, Morad M (1990) Modulation of the NMDA channel by extracellular $\mathrm{H}^{+}$. Proc Natl Acad Sci USA 87:6445-6450.

Taylor CP, Weber ML (1993) Effect of temperature on synaptic function after reduced oxygen and glucose in hippocampal slices. Neuroscience 52:555-562.

Thorn WG, Heitmann R (1954) pH der Gehirnrinde vom Kaninchen in situ wahrend perakuter, totaler Ischamie, reiner anioxie und in der Erholung. Pfluegers Arch Ges Physiol 261:334-360.

Tkachuk VA, Men'shikov MY (1981) Effect of $\mathrm{pH}$ on calcium binding properties of calmodulin and its interaction with the $\mathrm{Ca}$-dependent form of cyclic nucleotide phosphodiesterase. Biokhimia 46:779-788.

Tombaugh GC, Sapolsky RM (1990a) Mechanistic distinctions between excitotoxic and acidotic hippocampal damage in an in vitro model of ischemia. J Cereb Blood Flow Metab 10:527-535.

Tombaugh GC, Sapolsky RM (1990b) Mild acidosis protects hippocampal neurons from injury induced by oxygen and glucose deprivation. Brain Res 506:343-345.

Tombaugh GC, Sapolsky RM (1993) Evolving concepts about the role of acidosis in ischemic neuropathology. J Neurochem 61:793-803.

Traynelis S, Cull-Candy S (1990) Proton inhibition of NMDA receptors in cerebellar neurons. Nature 356:347-349.

Van Harrevald A (1959) Compounds in brain extracts causing spreading depression of cerebral cortical activity and contraction of crustacean muscle. J Neurochem 3:300-315.

Walz WW (1989) $\mathrm{pH}$ shifts evoked by neuronal stimulation in slices of rat hippocampus. Can J Physiol Pharmacol 67:577-581.

Walz WW, Harold DE (1989) Brain lactic acidosis and synaptic function. Can J Physiol Pharmacol 68:164-169.

Welsh FA, Sims RE, Harris VA (1990) Mild hypothermia prevents ischemic injury in gerbil hippocampus. J Cereb Blood Flow Metab 10:557-563.

Whittingham TS, Warman E, Assaf H, Sick TJ, LaManna JC (1989) Manipulating the intracellular environment of hippocampal slices: $\mathrm{pH}$ and high-energy phosphates. J Neurosci Methods 28:83-91.

Widmann R, Kuroiwa P, Bonnekoh P, Hossmann K-A (1991) $\left[{ }^{14} \mathrm{C}\right]$ leucine incorporation into brain proteins in gerbils after transient ischemia: relationship to selective vulnerability of hippocampus. $\mathrm{J}$ Neurochem 56:789-796.

Young JN, Aitken PG, Somjen GG (1991) Calcium, magnesium, and long-term recovery from hypoxia in hippocampal tissue slices. Brain Res 548:343-345. 